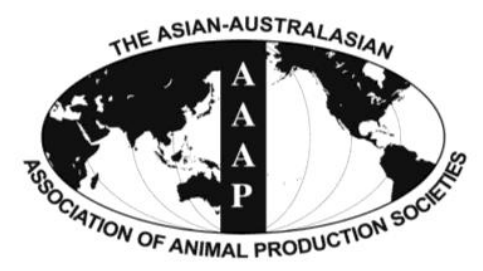

Asian-Aust. J. Anim. Sci.

Vol. 25, No. 9 : 1276 - 1284

September 2012

www.ajas.info

http://dx.doi.org/10.5713/ajas.2012.12128

\title{
Hematological Responses, Survival, and Respiratory Exchange in the Olive Flounder, Paralichthys olivaceus, during Starvation
}

\author{
I.-S. Park*, J. W. Hur ${ }^{1}$ and J. W. Choi \\ Department of Marine Environment and Bioscience, College of Ocean Science and Technology, \\ Korea Maritime University, Busan 606-791, Korea
}

\begin{abstract}
A 12-wk experiment was conducted to examine the hematological changes, survival, and respiratory exchange in the olive flounder, Paralichthys olivaceus, during starvation. The growth, survival and respiratory exchange rates of the starved group were lower than those of the fed group during the experiment. Blood analysis, including hematocrit, hemoglobin, red blood cells, mean corpuscular hemoglobin, mean corpuscular hemoglobin concentration, and mean corpuscular volume, did not differ significantly $(\mathrm{p}>0.05)$ between the fed and starved groups at the end of the experiment. There were no significant differences in plasma cortisol, glucose, $\mathrm{Na}^{+}, \mathrm{Cl}^{-}, \mathrm{K}^{+}$, or aspartate aminotransferase between the fed and starved groups ( $\mathrm{p}>0.05)$. Alanine aminotransferase levels were higher in the starved group than in the fed group, whereas plasma osmolality was lower in the starved group than in the fed group. It was shown that starved fish had various problems after four weeks, which did not occur in the fed group. Long-term starvation is infrequent in aquaculture farms. However, starvation studies of this kind are very useful for a basic understanding of how physiological changes affect fish health, life expectancy, and growth. (Key Words: Hematological Responses, Olive Flounder, Paralichthys olivaceus, Oxygen Consumption Rate, Respiration Frequency, Starvation, Stress)
\end{abstract}

\section{INTRODUCTION}

Most fish undergo periods of starvation during overwintering, spawning, migration, or geographic reductions in their food resources. Fish can overcome starvation using biochemical, physiological, and behavioral strategies. The endogenous energy derived from basic metabolites accumulated in the body is spent as the fish consume their own tissues to remain alive during periods of starvation (Weatherley and Gill, 1987; Lee et al., 1999).

The efficiency of oxygen consumption in fish is directly related to their metabolic processes, with which they synthesize body ingredients to produce physical energy. This, in turn, ultimately determines their population density, food supply, and production (Erez et al., 1990; Itazawa and Hanyu, 1991; Dalla et al., 1998). Mehner and Wieser (1994)

\footnotetext{
* Corresponding Author: I.-S. Park. Tel: +82-51-410-4321, Fax: +82-51-405-4322, E-mail: ispark@hhu.ac.kr

${ }^{1}$ Water Resources and Environmental Research Center, K-water Institute, Korea Water Resources Corporation, 462-1, Jeongmindong, Yuseong-gu, Daejeon 305-730, Korea.

Submitted Mar. 6, 2012; Accepted May 5, 2012; Revised May 29, 2012
}

observed a relationship between the depletion of energy reserves and changes in oxygen consumption in the perch, Perca fluviatilis. Starvation reduces oxygen consumption efficiency, as reported in perch larvae and the traira, Hoplias malabaricus, when they were subjected to extended periods of starvation (Mehner and Wieser, 1994; Rios et al., 2002).

Stresses on fish induce the release of catecholamine and cortisol, which cause the rapid metabolism of high-energy storage compounds (Barton and Iwama, 1991; Pickering, 1993). These catabolic processes have harmful biochemical effects on fish health and lead to slow growth (Specker and Schreck, 1980; Pickering, 1990). Fish exhibit primary, secondary, and tertiary responses to stress (Barton and Iwama, 1991). The primary response is manifested in rapid changes in plasma catecholamine and corticosteroid. When these responses to stressful conditions exceed normal levels, harmful secondary and tertiary responses occur. Therefore, stress induces changes in the energetic metabolic processes, reduces growth rate, disturbs reproduction, and leads to rapid changes in flesh quality after death (Barton and Iwama, 1991; Lowe et al., 1993; Wendelaar Bonga, 1997; 
Hur et al., 2001). Blood chemistry provides an indication of an animal's physiological state, and many factors (age, sex, nutrition, season, and circadian rhythm) may affect the blood chemistry. Information is available on the plasma glucose changes during starvation in the Atlantic cod, Gadus morhua L., the European eel, Anguilla anguilla (Larsson and Lewander, 1973), the pike, Esox lucius (Ince and Thorpe, 1976), the toadfish, Opsanus tau (Tashima and Cahill, 1968), the goldfish, Carassius auratus (Chavin and Young, 1970), and the American eel, Anguilla rostrata (Moon, 1983). Studies of plasma free fatty acids during starvation stress have also been performed in the European eel (Larsson and Lewander, 1973), the American eel (Moon, 1983), the rainbow trout, Oncorhynchus mykiss (Sumpter et al., 1991), the pike (Ince and Thorpe, 1976), and the toadfish (Tashima and Cahill, 1968). Rios et al. (2005) noted that erythrocyte senescence and hematological changes are induced by starvation in neotropical traira.

The olive flounder, Paralichthys olivaceus, has a flattened oval body, and mainly occurs in the benthos at depths of 10 to $200 \mathrm{~m}$, with a wide distribution in Korea and East Asia. Approximately 40,922 tonnes of this species were produced in Korea in 2010 (KNSO, 2011). The olive flounder may experience short- or long-term starvation, e.g., directly when feeding is arrested, or indirectly because of low water temperatures when cold water masses move into their habitat or during red tides in the warm summer season in Korea. Starvation is an important factor affecting the immune system, survival, and growth of the flounder (Hur et al., 2006a, 2006b). The main objective of this study was to examine the biochemical reactions and changes that occur in the olive flounder under long-term starvation stress, and to gather information that may be useful in designing the optimum feeding conditions for them, to improve their breeding and production. These findings can be readily applied in the aquaculture industry to estimate the optimal conditions for the olive flounder and to determine their nutritional indices.

\section{MATERIALS AND METHODS}

The olive flounder, Paralichthys olivaceus (mean body weight: $22.9 \pm 0.90 \mathrm{~g}$; mean total length: $100.7 \pm 11.70 \mathrm{~cm}$ ), used in this experiment were hatched in April, 2011, at a flounder farm and subsequently transported to a mariculture facility at the Fishery Genetics and Breeding Science Laboratory of the Korea Maritime University in Busan, Korea. At the start of the experiment, two experimental groups were established, the fed and the starved groups. All the fish were fed daily with a commercial feed (containing $50.0 \%$ crude protein, $8.0 \%$ crude lipid, $4.0 \%$ fiber, 15.0 ash, $1.5 \%$ calcium, $1.7 \%$ phosphorus, and $3.0 \%$ minerals) at between $1 \%$ and $3 \%$ of their total body weight for two weeks before the start of the experiment. The fed group was hand fed three times daily at $4 \mathrm{~h}$ intervals (the first feeding occurred between 08:00 and 12:00 $\mathrm{h}$, the second between 12:00 and 16:00 h, and the third between 16:00 and 20:00 h, but always with $4 \mathrm{~h}$ between successive feeds). The commercial feed employed before the start of the experiment was also used in fed group. The fed group received food ad libitum, whereas the starved group was fasted throughout the experiment.

The fish were raised in a recirculating system. They were placed in 1.1 ton fiberglass-reinforced circular tanks $(118 \mathrm{~cm}$ diameter $\times 100 \mathrm{~cm}$ depth). $20 \mathrm{fish}$ were accommodated in each of the tank. An electric timer was used to keep the photoperiod on a 12:12 h light/dark cycle. Oxygen consumption efficiency was determined in the fed and starved groups in a tank in which an oxyguard product (Handy polaris, Oxyguard, Denmark) measured the oxygen consumption at $10 \mathrm{~min}$ intervals. To monitor the changes in oxygen consumption volume, $20 \mathrm{~g} / \mathrm{L}$ density from the fed group and $18.8 \mathrm{~g} / \mathrm{L}$ density from the starved group was added to the tank and the water temperature was controlled with a circulating water bath (Johnsam, Korea). The initial water temperature in the tank was $22^{\circ} \mathrm{C}$, at which the fish were maintained for $24 \mathrm{~h}$. The oxygen consumption volumes were then estimated at $22^{\circ} \mathrm{C}$ for $48 \mathrm{~h}$ and every hour thereafter, as the temperature was increased in $1^{\circ} \mathrm{C}$ increments to $30^{\circ} \mathrm{C}$. The oxygen consumption volume of both the input and output were measured at 10 min intervals, and the data were automatically saved to a computer.

We calculated the oxygen consumption volume using the formula: $\mathrm{VO}_{2} \mathrm{mg} / \mathrm{kg} / \mathrm{h}=\left(\left(\mathrm{C}_{\mathrm{i}}-\mathrm{C}_{\mathrm{o}}\right) \times \mathrm{F} \times 60\right) / \mathrm{W}$, where $\mathrm{C}_{\mathrm{i}}=$ the dissolved oxygen consumption volume of the input $(\mathrm{mg} / \mathrm{L}), \mathrm{C}_{\mathrm{o}}=$ the dissolved oxygen consumption volume of the output $(\mathrm{mg} / \mathrm{L}), \mathrm{F}=$ flow rate $(\mathrm{L} / \mathrm{min})$, and $\mathrm{W}=$ total live weight of the fish $(\mathrm{kg})$. Respiration was determined from the average values. The parameters of seawater quality during the experiment were in the ranges: TN, 1.9 to 4.1 $\mathrm{mg} / \mathrm{L}$; TKN, 1.0 to $1.2 \mathrm{mg} / \mathrm{L} ; \mathrm{NH}_{4}{ }^{+}-\mathrm{N}, 0.9$ to $1.1 \mathrm{mg} / \mathrm{L}$; $\mathrm{NO}_{3}{ }^{-} \mathrm{N}, 0.9$ to $2.9 \mathrm{mg} / \mathrm{L}$; TP, 0.02 to $0.78 \mathrm{mg} / \mathrm{L} ; \mathrm{PO}_{4}{ }^{3-}-\mathrm{P}$, 0.004 to $0.351 \mathrm{mg} / \mathrm{L}$; COD, 2.0 to $11.1 \mathrm{mg} / \mathrm{L}$; water temperature, 19.4 to $22.4^{\circ} \mathrm{C}$; salinity, 34.0 to $37.0 \mathrm{psu}$; dissolved oxygen, 5.7 to $8.0 \mathrm{ppm}$; and $\mathrm{pH} 7.2$ to 7.8. The rotation rate was 30 times the water volume, and two-thirds of the water volume was replenished with natural seawater once a week. Table 2 shows the other water conditions during the experimental period. Each tank was covered with a net to prevent the fish from jumping out, and survival was recorded throughout the experiment.

Blood was sampled in 1 min without anesthesia from the caudal blood vessel complex using heparinized syringes on d 0 (before the start of the experiment, BE) and at 4, 8, and 12 wks after starvation stress. The hematocrit, red blood cells (RBC), and hemoglobin were analyzed 
immediately with an automatic blood analyzer (Excel 500, USA). The blood samples were kept in $2 \mathrm{ml}$ vacuum containers treated with sodium fluoride/potassium oxalate (Vacutainer, UK) and in $1.5 \mathrm{ml}$ polypropylene microcentrifuge tubes held on ice for less than $5 \mathrm{~min}$ before centrifugation at $5,600 \times \mathrm{g}$ for $5 \mathrm{~min}$. The plasma was then collected and stored in a deep freeze (CLN-500 UW Nihon Freezer; Nihon Co., Japan) at $-70^{\circ} \mathrm{C}$ until analysis. The plasma cortisol concentrations were determined in $50 \mu \mathrm{l}$ samples using radioimmunoassay kits (Coat-A-Count TKCO Cortisol RIA Kit; DPC, USA). Mixtures of samples in $100 \mathrm{ml}$ of antiserum were incubated for $45 \mathrm{~min}$ at $37^{\circ} \mathrm{C}$, and then $1,000 \mathrm{ml}$ of separation reagent was added. The mixtures were placed in a refrigerator at $4{ }^{\circ} \mathrm{C}$ for $15 \mathrm{~min}$, then centrifuged at $1,200 \times \mathrm{g}$ for $15 \mathrm{~min}$. The supernatants were assayed for $\gamma$-radiation using an automatic $\gamma$-counter (Cobra II; Packard Co., USA). Plasma glucose, lactic acid, aspartate aminotransferase (AST), alanine aminotransferase (ALT), $\mathrm{Na}^{+}, \mathrm{K}^{+}, \mathrm{Cl}^{-}$, and total protein were analyzed with an automatic chemical analyzer (Hitachi 7180, Hitachi, Japan). Osmolality was determined with a micro osmometer (Fiske 210; Fiske, USA).

The experiment was performed in triplicate and the results are reported as means $\pm \mathrm{SD}(n=10)$, unless otherwise stated. The data were analyzed with one-way ANOVA with the SPSS statistical package (SPSS 9.0, SPSS Inc., Chicago, IL, USA). Means were compared using Duncan's multiple range test and were considered significantly different at $\mathrm{p}<0.05$.

\section{RESULTS}

At the start of the experiment, the average total length and body weight of the olive flounder were $22 \pm 0.9 \mathrm{~cm}$ and $100 \pm 11.7 \mathrm{~g}$, respectively, in both groups. After $12 \mathrm{wks}$, total

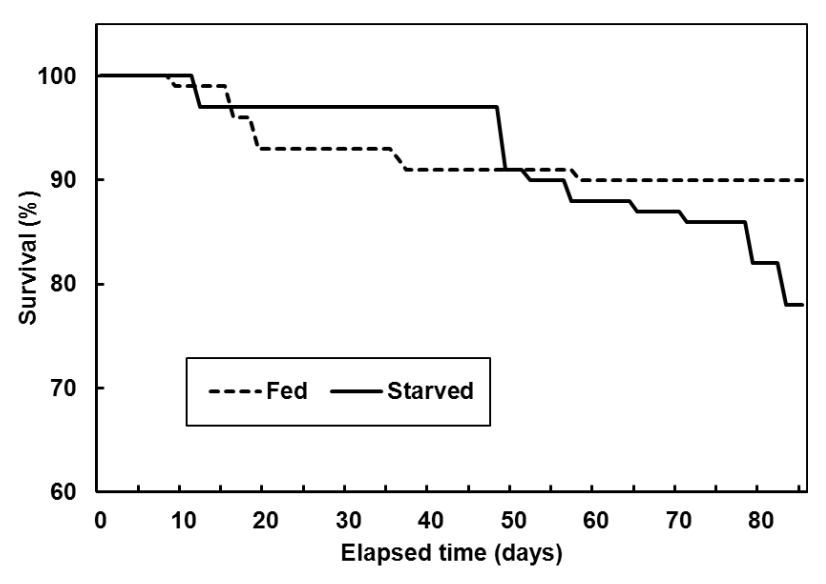

Figure 1. Mean survival of the olive flounder, Paralichthys olivaceus, fed and starved, in triplicate experiments.

length and body weight of the olive flounder in fed group were $31.2 \pm 1.94$ and $312.2 \pm 62.49 \mathrm{~g}$ respectively and total length and body weight of the olive flounder in starved group were $21.1 \pm 1.70 \mathrm{~cm}$ and $56.4 \pm 16.64 \mathrm{~g}$ respectively. The starved group had rapidly lost vitality, so the experiment was terminated. The cumulative survival was $90 \pm 1.2 \%$ in the fed group and $77 \pm 2.4 \%$ in the starved group in each of the triplicate tanks (Figure 1).

Figure 2 shows the changes in oxygen consumption observed in the $72 \mathrm{~h}$ immediately after the $12 \mathrm{wk}$ experiment. The average oxygen consumption volume between one and $48 \mathrm{~h}$, at $22^{\circ} \mathrm{C}$, was $112.2 \pm 18.06$ $\mathrm{mg} \mathrm{O}_{2} / \mathrm{kg} / \mathrm{h}$ for the fed group and $63.3 \pm 11.74 \mathrm{mg} \mathrm{O} / \mathrm{kg} / \mathrm{h}$ for the starved group $(\mathrm{p}<0.05)$. The water temperature was then increased incrementally at $1^{\circ} \mathrm{C} / \mathrm{h}$ to $30^{\circ} \mathrm{C}$ (i.e., total 57 $\mathrm{h}$ from $\left.0^{\circ} \mathrm{C}\right)$. At this stage, the oxygen consumption remained constant, even though the experiment continued for a further $15 \mathrm{~h}$ (i.e., $72 \mathrm{~h}$ in total). The average respiration values $48 \mathrm{~h}$ after the termination of the

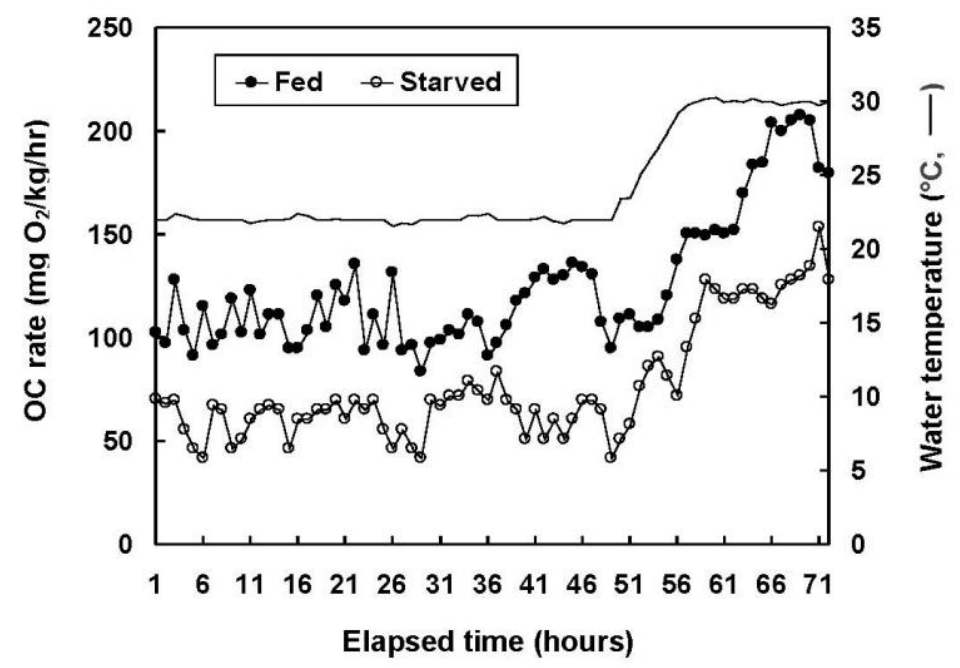

Figure 2. Oxygen consumption (OC) rate of the olive flounder, Paralichthys olivaceus, fed and starved for 12 wks. 


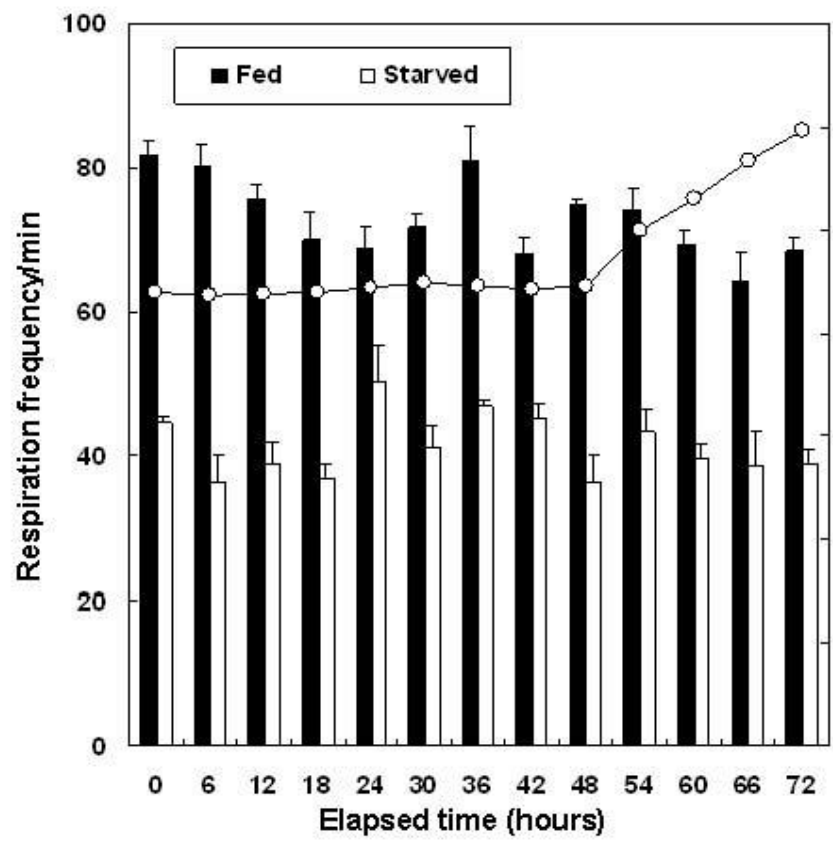

Figure 3. Respiration frequency of the olive flounder, Paralichthys olivaceus, fed and starved for 12 wks. Error bars represent standard deviations.

starvation experiment were $73.3 \pm 2.29$ frequency/min in the fed group and $41.4 \pm 1.80$ frequency/min in the starved group (Figure 3).

Table 1 shows the variations in hematocrit, hemoglobin,
$\mathrm{RBC}$, mean corpuscular volume (MCV), mean corpuscular hemoglobin $(\mathrm{MCH})$, and mean corpuscular hemoglobin concentration (MCHC) in the blood of the olive flounder in the fed and starved groups during the 12 wks of the

Table 1. Blood analysis of olive flounder, Paralichthys olivaceus, fed or starved for 12 wks

\begin{tabular}{|c|c|c|c|c|}
\hline \multirow{2}{*}{ Parameter } & \multicolumn{4}{|c|}{ Rearing period (wks) } \\
\hline & 0 & 4 & 8 & 12 \\
\hline \multicolumn{5}{|c|}{ Hematocrit (\%) } \\
\hline Fed & $29.2 \pm 4.10^{\mathrm{b}}$ & $19.3 \pm 3.43^{\mathrm{a}}$ & $29.4 \pm 5.82^{\mathrm{b}}$ & $28.1 \pm 2.78^{b}$ \\
\hline Starved & $29.2 \pm 4.10^{\mathrm{b}}$ & $19.6 \pm 0.35^{\mathrm{a}}$ & $32.3 \pm 8.53^{\mathrm{b}}$ & $32.3 \pm 5.17^{\mathrm{b}}$ \\
\hline \multicolumn{5}{|c|}{ Hemoglobin (g/dl) } \\
\hline Fed & $11.6 \pm 1.56^{\mathrm{a}}$ & $12.7 \pm 2.17^{\mathrm{ab}}$ & $15.4 \pm 1.11^{\mathrm{bc}}$ & $16.3 \pm 2.15^{\mathrm{c}}$ \\
\hline Starved & $11.6 \pm 1.56^{\mathrm{a}}$ & $14.4 \pm 0.31^{\mathrm{ab}}$ & $17.5 \pm 2.10^{\mathrm{bc}}$ & $20.5 \pm 4.54^{\mathrm{c}}$ \\
\hline \multicolumn{5}{|c|}{$\mathrm{RBC}\left(\times 10^{6} \mathrm{cell} / \mu \mathrm{l}\right)$} \\
\hline Fed & $4.9 \pm 0.34^{\mathrm{b}}$ & $2.9 \pm 0.52^{\mathrm{a}}$ & $4.1 \pm 1.04^{\mathrm{b}}$ & $3.9 \pm 0.20^{\mathrm{b}}$ \\
\hline Starved & $4.9 \pm 0.34^{\mathrm{b}}$ & $3.3 \pm 0.09^{\mathrm{a}}$ & $4.8 \pm 0.69^{\mathrm{b}}$ & $4.6 \pm 0.70^{\mathrm{b}}$ \\
\hline \multicolumn{5}{|l|}{$\mathrm{MCH}(\mathrm{pg})$} \\
\hline Fed & $59.7 \pm 4.25$ & $67.2 \pm 1.81$ & $72.1 \pm 5.85$ & $71.5 \pm 3.68$ \\
\hline Starved & $59.7 \pm 4.25$ & $59.3 \pm 2.68$ & $59.3 \pm 5.94$ & $69.8 \pm 3.32$ \\
\hline \multicolumn{5}{|c|}{ MCHC (g/dl) } \\
\hline Fed & $39.7 \pm 0.25^{\mathrm{a}}$ & $66.0 \pm 1.89^{\mathrm{b}}$ & $53.5 \pm 6.98^{\mathrm{bc}}$ & $58.5 \pm 9.25^{\mathrm{c}}$ \\
\hline Starved & $39.7 \pm 0.25^{\mathrm{a}}$ & $73.8 \pm 2.86^{\mathrm{b}}$ & $62.1 \pm 3.71^{\mathrm{b}}$ & $62.9 \pm 4.36^{\mathrm{b}}$ \\
\hline \multicolumn{5}{|l|}{ MCV (fl) } \\
\hline Fed & $60.0 \pm 4.24^{\mathrm{a}}$ & $44.4 \pm 1.43^{\mathrm{b}}$ & $38.7 \pm 6.92^{\mathrm{b}}$ & $41.7 \pm 5.52^{\mathrm{b}}$ \\
\hline Starved & $60.0 \pm 4.24^{\mathrm{a}}$ & $43.7 \pm 0.43^{c}$ & $36.7 \pm 1.46^{\mathrm{b}}$ & $44.0 \pm 4.29^{\mathrm{bc}}$ \\
\hline
\end{tabular}

The values are means $\pm \mathrm{SD}(n=10)$ of triplicate groups.

Means in each group of parameters with the same superscript letter are not significantly different ( $p>0.05)$.

$\mathrm{MCH}=$ Mean corpuscular hemoglobin $; \mathrm{MCHC}=$ Mean corpuscular hemoglobin concentration.

$\mathrm{MCV}=$ Mean corpuscular volume; $\mathrm{RBC}=$ Red blood cells. 

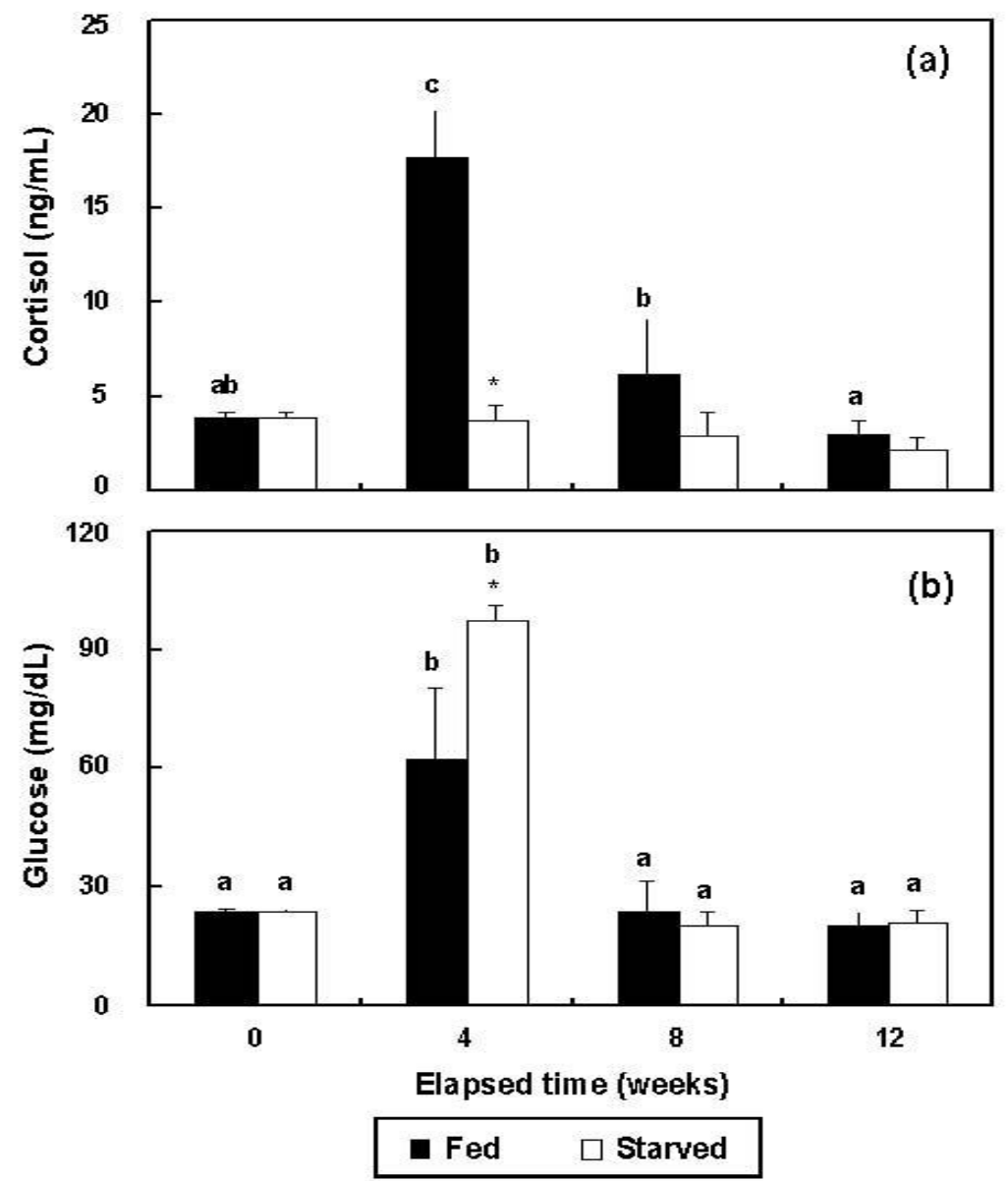

Figure 4. Variations during triplicate experiments in (a) cortisol and (b) glucose levels in the plasma of the fed and starved groups of olive flounder, Paralichthys olivaceus $(n=10)$. The same letters on the same-colored bars indicate no significant difference ( $p>0.05)$. * Indicates significant differences between the two groups at equivalent weeks.

experiment. The hematocrit decreased significantly ( $\mathrm{p}<0.05$ ) from $29.2 \pm 4.1 \%$ (BE) to $19.3 \pm 3.4 \%$ (fed group) and to $19.6 \pm 0.4 \%$ (starved group) in $4 \mathrm{wks}$, but there was no significant change between 8 and 12 wks $(p>0.05)$. The hemoglobin of the fed and starved groups increased significantly from $11.6 \pm 1.56 \mathrm{~g} / \mathrm{dl}$ (BE) to $15.4 \pm 1.1$ (8 wks) and $16.3 \pm 2.2 \mathrm{~g} / \mathrm{dl}(12 \mathrm{wks})(\mathrm{p}<0.05)$ in the fed group and to $17.5 \pm 2.1$ and $20.5 \pm 4.5 \mathrm{~g} / \mathrm{dl}$, respectively $(\mathrm{p}<0.05)$, in the starved group. The RBC of the two groups had decreased significantly at $4 \mathrm{wks}(\mathrm{p}<0.05)$ relative to $\mathrm{BE}$, but was not significantly different from 4 wks at 8 or 12 wks. The hematocrit, hemoglobin, $\mathrm{RBC}, \mathrm{MCH}, \mathrm{MCV}$, and $\mathrm{MCHC}$ of the two groups in equivalent weeks were not significantly affected $(p>0.05)$ by the feeding/starvation regimen during the experimental period.

In the fed group, plasma cortisol increased significantly ( $\mathrm{p}<0.05$ ) from $3.9 \pm 0.3 \mathrm{ng} / \mathrm{ml}(\mathrm{BE})$ to $17.7 \pm 2.5 \mathrm{ng} / \mathrm{ml}$ at 4 wks, but at $8(6.2 \pm 2.9 \mathrm{ng} / \mathrm{ml})$ and $12 \mathrm{wks}(3.0 \pm 0.7 \mathrm{ng} / \mathrm{ml})$, the changes were not significant from 4 wks $(p>0.05)$ (Figure 4a). The cortisol of the starved group did not change significantly during the experimental period, ranging from $2.2 \pm 0.7 \mathrm{ng} / \mathrm{ml}$ to $3.9 \pm 0.3 \mathrm{ng} / \mathrm{ml}(\mathrm{p}>0.05)$. The glucose concentrations of the two groups increased significantly from $23.5 \pm 0.7 \mathrm{mg} / \mathrm{dl}(\mathrm{BE})$ to $62.0 \pm 18.4$ (fed) and $97.3 \pm 3.9 \mathrm{mg} / \mathrm{dl}$ (starved) at 4 wks $(\mathrm{p}<0.05$ for both) (Figure $4 \mathrm{~b}$ ). The glucose levels of the fed and starved groups did not differ significantly from 4 weeks to 12 wks $(p>0.05)$. At 4 wks, the cortisol and glucose levels of the fed and starved groups differed significantly $(\mathrm{p}<0.05)$.

The $\mathrm{Na}^{+}, \mathrm{Cl}^{-}$, and $\mathrm{K}^{+}$levels of the starved group did not change significantly $(\mathrm{p}>0.05)$, and at equivalent weeks, were not significantly affected by the feeding/starvation regimen during the experimental period (Table 2). In the starved group, the AST concentrations increased significantly $(\mathrm{p}<0.05)$ from $6.0 \pm 0.1 \mathrm{IU} / \mathrm{L}(\mathrm{BE})$ to $13.8 \pm 1.9$ $\mathrm{IU} / \mathrm{L}$ at $4 \mathrm{wks}, 12.0 \pm 1.8 \mathrm{IU} / \mathrm{L}$ at $8 \mathrm{wks}$, and $15.5 \pm 3.0 \mathrm{IU} / \mathrm{L}$ at 12 wks (Table 2), and the ALT concentrations at 4, 8, and 12 wks were significantly $(\mathrm{p}<0.05)$ higher than the $\mathrm{BE}$ concentration. The AST and ALT concentrations in the fed group did not change significantly $(p>0.05)$ during the experimental period. The AST and ALT concentrations in the starved group at 4,8 , and 12 wks were significantly 
Table 2. Variations in $\mathrm{Na}^{+}, \mathrm{Cl}^{-}, \mathrm{K}^{+}$, AST, ALT, and osmolality in the plasma of the olive flounder, Paralichthys olivaceus, fed or starved for $12 \mathrm{wks}$

\begin{tabular}{|c|c|c|c|c|}
\hline \multirow{2}{*}{ Parameter } & \multicolumn{4}{|c|}{ Rearing period (wks) } \\
\hline & 0 & 4 & 8 & 12 \\
\hline \multicolumn{5}{|c|}{$\mathrm{Na}^{+}(\mathrm{mEq} / \mathrm{L})$} \\
\hline Fed & $163.0 \pm 0.01$ & $165.4 \pm 1.11$ & $164.3 \pm 5.51$ & $160.8 \pm 0.96$ \\
\hline Starved & $163.0 \pm 0.01$ & $164.0 \pm 1.87$ & $158.5 \pm 4.43$ & $159.5 \pm 1.73$ \\
\hline \multicolumn{5}{|c|}{$\mathrm{Cl}^{-}(\mathrm{mEq} / \mathrm{L})$} \\
\hline Fed & $134.5 \pm 0.71^{\mathrm{ab}}$ & $141.9 \pm 1.03^{\mathrm{b}}$ & $137.0 \pm 4.36^{\mathrm{ab}}$ & $132.3 \pm 2.50^{\mathrm{a}}$ \\
\hline Starved & $134.5 \pm 0.71$ & $140.1 \pm 3.52$ & $135.3 \pm 5.74$ & $139.3 \pm 1.71$ \\
\hline \multicolumn{5}{|c|}{$\mathrm{K}^{+}(\mathrm{mEq} / \mathrm{L})$} \\
\hline Fed & $3.7 \pm 0.14$ & $3.6 \pm 0.44$ & $3.3 \pm 0.56$ & $3.4 \pm 0.25$ \\
\hline Starved & $3.7 \pm 0.14$ & $3.6 \pm 0.19$ & $3.5 \pm 0.16$ & $3.3 \pm 0.21$ \\
\hline \multicolumn{5}{|c|}{ AST (IU/L) } \\
\hline Fed & $6.0 \pm 0.01$ & $4.6 \pm 2.95 *$ & $8.7 \pm 7.23 *$ & $11.8 \pm 6.60^{*}$ \\
\hline Starved & $6.0 \pm 0.01^{\mathrm{a}}$ & $13.8 \pm 1.94^{\mathrm{b}}$ & $12.0 \pm 8.83^{\mathrm{b}}$ & $15.5 \pm 3.00^{\mathrm{b}}$ \\
\hline \multicolumn{5}{|c|}{ ALT (IU/L) } \\
\hline Fed & $2.0 \pm 0.00$ & $2.1 \pm 0.47^{*}$ & $2.2 \pm 0.09 *$ & $2.3 \pm 0.50 *$ \\
\hline Starved & $2.0 \pm 0.00^{\mathrm{a}}$ & $11.8 \pm 1.19^{\mathrm{b}}$ & $10.3 \pm 0.50^{\mathrm{b}}$ & $10.0 \pm 1.60^{\mathrm{b}}$ \\
\hline \multicolumn{5}{|c|}{ Osmolality (mOsm/kg) } \\
\hline Fed & $403.5 \pm 17.67$ & $389.3 \pm 15.90^{*}$ & $379.0 \pm 14.53$ & $383.5 \pm 21.83 *$ \\
\hline Starved & $403.5 \pm 17.67^{\mathrm{b}}$ & $351.3 \pm 3.30^{\mathrm{a}}$ & $352.3 \pm 16.66^{\mathrm{a}}$ & $346.5 \pm 18.67^{\mathrm{a}}$ \\
\hline
\end{tabular}

The values are means $\pm \mathrm{SD}(n=10)$ of triplicate groups.

Means in each group of parameters with the same superscript letter are not significantly different $(\mathrm{p}>0.05)$.

* Indicates significant differences between the two groups at equivalent weeks $(\mathrm{p}<0.05)$.

ALT $=$ Alanine aminotransferase $;$ AST $=$ Aspartate aminotransferase.

higher than those in the fed group $(\mathrm{p}<0.05)$. The osmolality of the starved group decreased significantly $(\mathrm{p}<0.05)$ from $403.5 \pm 17.7 \mathrm{mOsm} / \mathrm{kg}$ (BE) to $351.3 \pm 3.3 \mathrm{mOsm} / \mathrm{kg}$ at $4 \mathrm{wks}$, $352.3 \pm 16.7 \mathrm{mOsm} / \mathrm{kg}$ at $8 \mathrm{wks}$, and $346.5 \pm 18.7 \mathrm{mOsm} / \mathrm{kg}$ at 12 wks (Table 2). The osmolality in the fed group at four and 12 wks was significantly higher than that in the starved group $(\mathrm{p}<0.05)$.

\section{DISCUSSION}

Fish deal with imposed starvation by using their accumulated energy stores (Love, 1970). However, this entails compensatory responses, such as a reduction in somatic growth (Weatherley and Gill, 1987). To endure starvation, fish require a basic amount of energy to maintain their metabolism, and storage products in the body provide most of this energy. Studies of starvation have provided basic information on the nutritional conditions and growth in wild and cultivated fish (Weatherley and Gill, 1987; Lee et al., 1998; Park et al., 2001). During starvation, essential processes are maintained at the expense of accumulated (i.e., completely endogenous) energy reserves, resulting in the progressive depletion and wastage (degrowth) of body tissues (Weatherley and Gill, 1987).

When a fish is exposed to chronic stress, its metabolic reactions are altered by changes in the hypothalamicpituitary-adrenocortical axis (HPA axis), with the hypothalamic secretion of corticotropin-releasing hormone (CRH) through the limbic system and by the reticular formation. $\mathrm{CRH}$ stimulates the release of adrenocorticotropic hormone (ACTH) from the pituitary gland, which then stimulates the release of cortisol from the target organ, the interrenal gland, promoting a metabolic stress reaction. Thus, cortisol is an important index of the stress reaction (Specker and Schreck, 1980). Severe starvation results in coma and catabolic disease of the gastrointestinal system. Basic metabolic reactions maintain energy levels and bodily tissues (Jung et al., 2003). Guyton (1991) reported three stages of physiological change during starvation: in the first stage, the glycogen stored for urgent use is hydrolyzed, releasing glucose; in the second stage, acetyl CoA is oversupplied relative to oxaloacetate (because of lipid use), leading to acidosis; and in the third stage, the fish are compromised by protein exhaustion. In the process of starvation, sugars, lipids, proteins, and other essential nutritional elements decrease rapidly, and finally, total abnormalities in the immune, circulatory, and endocrine systems lead to death.

In this study, the plasma cortisol concentrations were high in the fed group at 4 and 8 wks, but did not differ from 
those of the starved group of fish. Glucose in both groups increased up to 4 wks, but after 4 wks, it decreased to below $\mathrm{BE}$ or remained unchanged. Under chronic stresses other than starvation, the levels of cortisol (secreted by the HPA axis) and related metabolic products remain elevated over the long term. However, cortisol and its metabolically related products increase in the early stages of starvation stress, allowing rapid adaptation to a life-threatening process. However, if starvation is chronic, the reaction disappears (Jung et al., 2003). In the later stages of starvation, the levels of these factors decrease considerably (they are used as energy sources), with the consequent destruction of the internal organs and muscles, together with extreme atrophy of the fat tissues, with negative consequences for survival (Hur et al., 2006a, 2006b). Furthermore, according to Harris and Bird (2000), if the cortisol levels increase, the immune faculties decrease, which negatively affects growth and life expectancy.

This study has shown that at 4 wks cortisol increased in the fed group of fish. However, in the starved group, the cortisol levels were not elevated, although the levels of glucose were higher than BE, indicating the use of stored glycogen. At this stage, starvation had little effect on survival. In the rainbow trout, Oncorhynchus mykiss, there was significantly more cortisol in animals starved for 1 to 3 wks than in fed fish, but at 4 wks, there was no difference between the two groups (Sumpter et al., 1991). In the same species, the growth hormone increased much more in the starved group than in the fed group between wks 1 and 4 of the experimental period (Sumpter et al., 1991). We did not measure cortisol in the olive flounder, Paralichthys olivaceus, before $4 \mathrm{wks}$ of starvation, but at $4 \mathrm{wks}$, our findings were consistent with those for rainbow trout. We did not analyze the growth hormone levels. However, if the results for rainbow trout can be extrapolated to the olive flounder, starvation may have a greater effect on growth hormone than on cortisol.

As mentioned above, starvation is also related to the metabolic processes of the olive flounder. The metabolic processes are reduced during starvation to maintain energy. In this study, oxygen consumption and respiratory frequency were reduced during starvation to maintain energy, and these are also affected by water temperature. Gardner and King (1923) reported that the oxygen consumption volumes of fish increase with increasing water temperature. Wi and Chang (1976) also pointed to the $\mathrm{Q}_{10}$ law, which states that the oxygen consumption volume is related to the water temperature. The traira, $H$. malabaricus, maintained a constant respiratory exchange rate as its oxygen intake was reduced by anemia, which resulted in a reduction in its RBC and hematocrit during starvation (Rios et al., 2002). The constant respiratory exchange rate maintained by the traira was probably necessary to overcome its reduced blood oxygen-carrying capacity. In contrast, the results of Hur et al. (2006b) showed that the olive flounder maintained a continuously low oxygen consumption rate and a constant respiratory exchange rate, with no changes in RBC or hematocrit. In this study, the oxygen consumption of the fed group was higher than that of the starved group, consistent with the results of Gardner and King (1923) and Wi and Chang (1976) under increasing water temperatures. Because the oxygen consumption and respiratory exchange rates are an indication of energy consumption, the starved group might have exhibited hypometabolism compared with the fed group (Rios et al., 2002),

The hematocrit, hemoglobin, $\mathrm{RBC}$, and $\mathrm{MCH}$ (blood analysis factors) did not differ between the fed and starved groups of olive flounder. The hematocrit increased with starvation in the rainbow trout and pike, Esox lucius, but decreased in the European eel, Anguilla anguilla, so this response is species specific (Larsson and Lewander, 1973; Ince and Thorpe, 1976). Love (1970) predicted that the reduction in hematocrit values during starvation could reduce the fish's capacity to create $\mathrm{RBC}$, but we found that the RBC count in the starved group did not decrease until the end of the experiment. Starvation had no effect on the blood osmotic pressure, $\mathrm{Na}^{+}, \mathrm{Cl}^{-}$, or $\mathrm{K}^{+}$, but the level of osmolality decreased in the starved group more than in the fed group. After four weeks, the starved animals showed inconsistent osmoregulation. Ion regulation to control osmotic pressure requires energy, and this presents difficulties after four weeks of starvation, when reserves are precariously low. AST and ALT are aminotransferases distributed in the liver and spleen. Their plasma levels are low when animals are healthy, but increase when tissue necrosis is present or when animals become sick. Davis and Parker (1990) reported that the hemodynamic indices of the oxygen-carrying capacity are increased by stress. Longterm starvation causes changes in the liver (Hur et al., 2006a), and the liver is considered normal when hepatocytes have clear, distinct nuclei, as were observed initially and in the fed animals (Hur et al., 2006a). In starved animals, liver atrophy is apparent: the liver appears shrunken and contains darkly stained hepatocytes with evenly stained cytoplasm and indistinct, irregular nuclei. In starved animals, very few intracellular spaces are observed in the hepatocyte cytoplasm, in contrast to the extensive intracellular spaces in those of fed animals. The AST and ALT levels in the study group were significantly elevated by stress, suggesting that long-term starvation places physiological burdens on the liver and spleen.

We have shown that the fish had various problems after starvation for four weeks, which did not occur in the fed 
group. Long-term starvation is infrequent in aquaculture farms. However, starvation studies of this kind are very useful for a basic understanding of how physiological changes affect the health, life expectancy, and growth of fish.

\section{ACKNOWLEDGEMENTS}

This research was funded through project 20100021293 of the National Research Foundation of Korea. The authors thank the technical staff of the Laboratory for Fishery Genetics and Breeding Science at Korea Maritime University, Korea, for their helpful support, and the anonymous reviewers who greatly improved the quality of this manuscript. All procedures used in this study complied with current laws of Korea (Ordinance of Agriculture, Food and Fisheries, No. 1 and the law pertaining to experimental animals, No. 9932).

\section{REFERENCES}

Barton, B. A. and G. K. Iwama. 1991. Physiological changes in fish from stress in aquaculture with emphasis on the response and effects of corticosteroids. Annu. Rev. Fish Dis. 1:3-26.

Chavin, W. and J. E. Young. 1970. Facters in the determination of normal serum glucose levels of goldfish, Carassius auratus L. Comp. Biochem. Physiol. 33:629-653.

Dalla, V., J. P. Villani, E. Gasteiger and H. Niederstätter. 1998. Oxygen consumption in sea bass fingerling Dicentrarchus labrax exposed to acute salinity and temperature change: metabolic basis for maximum stocking density estimations. Aquaculture 169:303-313.

Davis, K. B. and N. C. Parker. 1990. Physiological stress in striped bass: effect of acclimation temperature. Aquculture 91:349-358.

Erez, J., M. D. Krom and T. Neuwirth. 1990. Daily oxygen variations in marine fish pons, elat, Israel. Aquaculture 84: 289-305.

Gardner, J. A. and G. King. 1923. Respiratory exchange in freshwater fish. Part VI. On pike (Esox lucius). Biochem. J. 17: 170-173.

Guyton, A. C. 1991. Texbook of medical physiology. 8th, (Ed. M. J. Wonsiewiez and R. Hallowell), WB Saunders Company, Philadelphia, p. 782.

Harris, J. and D. J. Bird. 2000. Modulation of the fish immune system by hormones. Vet. Immunol. Immunopathol. 77:163176.

Hur, J. W., J. H. Jo and I. -S. Park. 2006a. Effects of long-term starvation on hepatocyte ultrastructure of olive flounder, Paralichthys olivaceus. Ichthyol. Res. 53:306-310.

Hur, J. W., S. R Woo, J. H. Jo and I. -S. Park. 2006b. Effects of starvation on kidney melano-macrophage center in olive flounder, Paralichthys olivaceus (Temminck et Schlegel). Aquac. Res. 37:821-825.

Hur, J. W., Y. J. Chang, H. K. Lim and B. K. Lee. 2001. Stress responses of cultured fishes elicited by water level reduction in rearing tank and fish transference during selection process. J.
Korean Fish. Soc. 34:465-472.

Ince, B. W. and A. Thorpe. 1976. The effects of starvation and force-feeding on the metabolism of the northern pike, Esox lucius L. J. Fish Biol. 8:79-88.

Itazawa, Y. and I. Hanyu. 1991. Fish physiology. Koseisha Koseikaku, Tokyo, Japan, p. 621.

Jung, M. H., J. M. Youn and T. H. Lee. 2003. Effect of liriopis tuber on the chang of corticosterone in mice induced by starvation stress. Korea J. Herbology 18: 279-287.

Larsson A. and A. Lewander. 1973. Metabolic effects of starvation in the eel, Anguilla Anguilla L. Comp. Biochem. Physiol. 44A: 367-374.

Lee, C. K., I. -S. Park and S. B. Hur. 1998. Influence of starvation on the variations of hepatocyte nucleus in larvae of red spotted grouper, Epinephelus akaara. J. Aquacult. 11:11-17.

Lee, K. K., Y. H. Kim and I. -S. Park. 1999. Effect of starvation on some nutritional parameters in Rhynchocypris oxycephalus. 1. Charateristics of the histological and biochemical changes. Korean J. Ichthyol. 11:33-41.

Love, R. M. 1970. Depletion. In: The Chemical Biology of Fishes with a Key to the Chemical Literature, Academic Press, London, pp. 222-257.

Lowe, T. E., J. M. Ryder, J. F. Carragher and R. M. G. Wells. 1993. Flesh quality in snapper, Pagrus auratus, affected by capture stress. J. Food Sci. 58:770-773.

Mehner, T. and W. Wieser. 1994. Energetics and metabolic correlates of starvation in juvenile perch (Perca fluviatilis). J. Fish Biol. 45:325-333.

Moon, T. W. 1983. Metabolic reserves and enzyme activities with food deprivation in immature American eels, Anguilla rostrata (Lesueur). Can. J. Zool. 61:802-811.

Park, I. -S., J. H. Im, D. K. Ryu, Y. K. Nam and D. S. Kim. 2001. Effect of starvation on morphometric changes in Rhynchocypris oxycephalus (Sauvage and Dabry). J. Appl. Ichthyol. 17:277-281.

Pickering, A. D. 1990. Stress the suppression of somatic growth in teleost fish. In: Progress in Comparative Endocrinology (Ed. A. Epple, C. G. Scanes and M. H. Stetson). Wiley-Liss, New York, 473-479.

Pickering, A. D. 1993. Growth and stress in fish production. Aquaculture 111:51-63.

Rios, F. S., A. L. Kalinin and F. T. Rantin. 2002. The effects of long-term food deprivation on respiration and haematology of the meotropical fish Hoplias malabaricus. J. Fish Biol. 61:8595.

Rios, F. S., E. T. Oba, M. N. Fernandes, A. L. Kalinin and F. T. Rantin. 2005. Erythrocyte senescence and haematological changes induced by starvation in the neotropical fish traíra, Hoplias malabaricus (Characiformes, Erythrinidae). Comp. Biochem. Physiol. 140A:281-287.

Specker, J. L. and C. B. Schreck. 1980. Stress response to transportation and fitness for marine survival in coho salmon (Oncorhynchus kisutch) smolts. Can. J. Fish. Aquat. Sci. 37: 765-769.

Sumpter, J. P., P. Y. Le Bail, A. D. Pickering, T. G. Pottinger and J. F. Carragher. 1991. The Effect of starvation on growth and plasma growth hormone concentrations of rainbow trout, Oncorhynchus mykiss. Gen. Comp. Endocrinol. 83: 94-102. 
Tashima, L. and C. F. Cahill. 1968. Effects of insulin in the Wendelaar Bonga, S. E. 1997. The stress response in fish. Physiol. toadifish, Opsanus tau. Gen. Comp. Endocrinol. 11:262-271. Rev. 77:591-625.

Weatherley, A. H. and H. S. Gill. 1987. The biology of fish growth. Wi, J. H. and Y. J. Chang. 1976. A basic study on transport of live 4. Protein, lipid and caloric contents. Academic press, London, fish (I). Bull. Fish. Res. Dev. Inst. Kor. 15:91-108. pp. 139-146. 